\title{
ОСОБЕННОСТИ ТЕРАПИИ САХАРНОГО ДИАБЕТА У ЛИЦ СО СТАРЧЕСКОЙ АСТЕНИЕЙ
}

\author{
Калинникова Л.А., Гринькова Л.В., Рунова А.А., Шамова С.А. \\ ФГБОУ ВО «ПИМУ» Минздрава России, Нижний Новгород
}

ЦЕЛЬ: оценить особенности гериатрических синдромов у пациентов с сахарным диабетом 2 типа и старческой астенией.

МАТЕРИАЛЫ И МЕТОДЫ: в Исследование включено 276 больных с сахарным диабетом тип 2 старшей возрастной группы, получавших лечение в эндокринологическом отделении. Средний возраст составил 76,4 года, стаж диабета 14ะ0,04 года. Всем больным был проведен скрининг синдрома старческой астении на основании шкалы «Возраст не помеха». В результате проведенного опроса в 33,4\% пациентов выявлен синдром старческой астении. У них проведена комплексная гериатрическая оценка, включающая краткую шкалу оценки психического статуса (MMSE), тест рисования часов, гериатрическую шкалу депрессии (GDS-15), шкалу базовой активности в повседневной жизни (индекс Бартел), шкалу повседневной инструментальной активности (IADL), краткую шкалу оценки питания (MNA), способность выполнения основных функций, а также визуально-аналоговую шкалу самооценки состояния здоровья (ВАШ), исследовалось наличие саркопении (метод динамометрии). Склонность к падениям оценивалась по тесту «встань и иди», тесту «скорость ходьбы» и по тандемному и полутандемному тесту.

РЕЗУЛЬТАТЫ: в результате проведенных исследований выявлено, что в 40,2\% у пациентов с сахарным диабетом присутствуют более 5 гериатрических синдромов. И только в 2,1\% пациенты имели менее трех гериатрических синдромов. В большей степени отмечалось снижение когнитивных функций - 49.2\%, склонность к падениям - в $32.5 \%$ и снижение инструментальной зависимости - в $24.3 \%$.

Несмотря на то, что в 56,2\% пациенты имели избыточный вес, синдром саркопении выявлен у $43.1 \%$ пациентов с сахарным диабетом и старческой астенией.

У $28,6 \%$ у пациентов отмечался такой гериатрический синдром, как недержание мочи. Нарушения по шкале базовой активности в повседневной жизни (индекс Бартел) более 60 баллов, что характеризует умеренную зависимость, отмечались в 70,5\%, независимые составили 19,9\%и 9.6\% составили пациенты с выраженной зависимостью от посторонней помощи.

ВЫВОды: наличие у пациента старческой астении является основанием для применения специального подхода к лечению, учитывающего наличие гериатрических синдромов, особенно склонность к падениям, снижение скорости ходьбы, саркопению и наличие когнитивных нарушений. Подход к лечению пациентов с синдромом старческой астении должен основываться и на результатах проведенной комплексной гериатрической оценки. 